\title{
System Design of Three Phases Six Legs DC/DC Converter for Solar Cell
}

\author{
Muhammad Prihadi Eko Wahyudi', Qoriatul Fitriyah ${ }^{1}$, Novie Ayub Windarko \\ ${ }^{1}$ Electrical Engineering Department, Politeknik Negeri Batam, Batam, Indonesia \\ ${ }^{2}$ Electrical Engineering Department, Politeknik Elektronika Negeri Surabaya, Surabaya, Indonesia \\ prihadieko@polibatam.ac.id, fitriyah@ polibatam.ac.id, ayub@pens.ac.id
}

\begin{abstract}
DC to DC converter 3 phase six legs for solar PV. The prototype is built with $5 \mathrm{kHz}$ transformers, 2 lead-acid batteries with each energy storage of 12V, 7.2Ah and 20WP solar PV. Three phase switching is provided by analog op-amp comparator circuit with variable frequency $1 \mathrm{kHz}-$ $20 \mathrm{kHz}$. The controller of the converter use adjustable DC power supply as voltage reference for analog op-amp comparator, works varies from $0-11 \mathrm{VDC}(0 \%-50 \%$ duty cycle) and controlled manually.
\end{abstract}

Keywords: DC to DC Converter, Full Bridge, six legs three phase, inverter, solar cell

\section{INTRODUCTION}

For several renewable energy resources, solar PV is one of them which has to be considered. It can provide reliable electric power for almost all electrical applications, convenience to collect, clean, quiet and fuel-free. [1]

Changrong Liu in his dissertation (page 23) says that the major features of this converter are:

1. Able to improve power rating by phase parallelize, not by performing whole unit parallel.

2. Able to increase voltage output dramatically by transformer delta-y connection without adding more coil windings.

3. Able to reduce value of capacitor as output filter

4. Able to reach zero voltage - zero current switching.

It is stated by Fabregat [2] and Tse, K.K [3], Solar $\mathrm{PV}$ is one of the renewable electrical energy resources, has its own unique output power characteristic which is dependent to material, load impedance, temperature and solar lighting. Maximum Power Point Tracker or abbreviated as MPPT;is an important step in order to gain the maximal value of solar PV output power as reviewed by Bhatnagar [4] with several methods such as OVC and SCC based on MPPT, look up table method, curve fitting based MPPT, PO method, and INC MPPT. Other related researches about MPPT state that MPPT can also work using frequency modulation, fuzzy logic, and PI, as it has been observed by Efticios [5] that; MPPT successfully optimized using several algorithms including PI controller. However, due to most of the researches are using only DC/DC buckboost converter as the MPPT medium, the application is basically used at relatively low power solar PV. DC/DC buck-boost converter application actually can be used in higher power appliances, such mentioned at Zang Fan research [6], but it has to be mounted in parallel and therefore will increase cost and component used in the designated application.

Other studies regarding power electronic technology has been done to streamline DC/DC converter by improving soft-switching PWM technique using full-bridge converter [7].

Some of these studies have their own advantages and disadvantages depend on the aim of the research. This study, however, will implement several combinations from related researches in order to apply the maximum power point tracking of solar PV using $\mathrm{DC}$ to DC converter.

\section{Metodology}

In this prototype device, DC/DC converter three phase six legs is able to be used as impedance controller for solar PV and can be combined with MPPT method by adjusting the reference voltage range of 0-11VDC. DC/DC converter 3 phases 6 legs is applied to maximize power output from a solar PV 20W. At the power storage side, used two lead-acid battery model No. LC-V127R2NA 12V 7,2Ah.

In broad outline, this study had circuit such as follows:

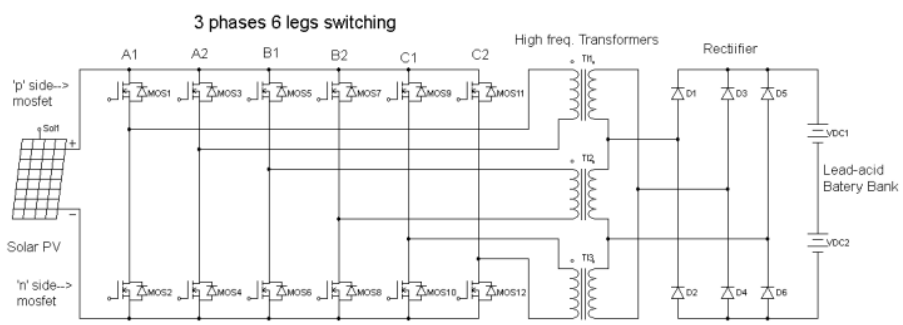

Figure 1

Lay out 3 phases 6 legs dc/dc converter for solar PV battery charging 
Figure 1 shows the experimental setup consisting of a single solar PV module with STC maximum power $20 \mathrm{~W}$, maximum voltage power $17.6 \mathrm{~V}$, maximum current power $1.14 \mathrm{~A}$, Isolated $\mathrm{DC} / \mathrm{DC}$ converter 3 phase 6 legs and lead-acid battery bank storage, $12 \mathrm{~V}$ and 7,2Ah each. The solar PV connected parallel with 6 legs N-channel mosfet to convert DC voltage of solar PV into AC signal voltage. The output of the 6 legs switching then get raised using 3 single phase $5 \mathrm{KHz}$ transformer connected delta at the output. The transformer output then get rectified using three halfbridge rectifier to charge the battery. The battery bank storage consists of two $12 \mathrm{~V}, 7.2$ Ah lead-acid battery connected in series, and the operating range of the battery bank range of 25-28VDC based on daily testing.

In the other hand, 3 phase switching for the mosfets are provided by analog op-amp circuit. The circuit consist of square wave generator and two op-amp integrator circuits to produce sine wave signal, two phase delay op-amp circuits, three inverter op-amp circuits, and six comparator op-amp circuits.

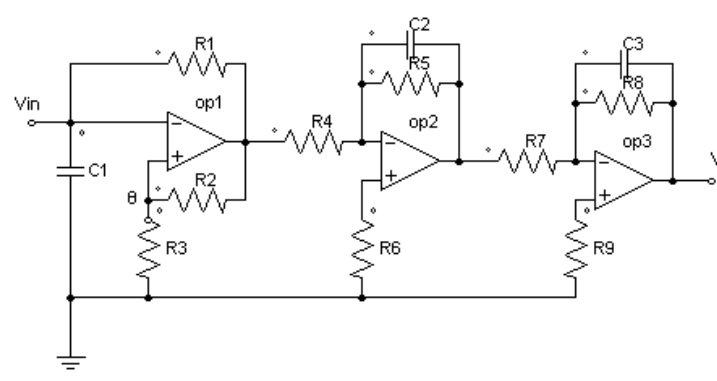

Figure 2

Sine wave generator circuit

The first op-amp (op1) in figure 2 will generate the square wave at the specific frequency depending on voltage divider $(\theta)$ as adapting reference and $\mathrm{RC}$ at the input side. The frequency of signal generator can also be calculated. The second and the third op-amp circuit in figure 2 will convert the square wave into sine wave. The concept of op2 and op3 is inverting amplifier with RC low-pass-filter.

\section{DESIGN AND RESULT}

The component type and detail can be seen on table 1 as follows;

Table 1.

Component Parameters used to the System

\begin{tabular}{|c|c|}
\hline Voc Solar PV & 21,6V \\
\hline Isc Solar PV & $1,21 \mathrm{~A}$ \\
\hline Transformer Core Material & Ferrite \\
\hline Transformer Core Type & PQ 35/35 \\
\hline Transformer Turns Ratio & $1 ; 2$ \\
\hline Switching Frequency & $5 \mathrm{KHz}$ \\
\hline Batery Model & LC-V127R2NA \\
\hline Batery type & Lead-Acid \\
\hline
\end{tabular}

\begin{tabular}{|c|c|}
\hline Batery voltage Stand by & $13,6-13,8 / 25^{\circ} \mathrm{C}$ \\
\hline Batery capacity & $7,2 \mathrm{Ah} / 20 \mathrm{~h}$ \\
\hline
\end{tabular}

The inverter itself consisted of six legs to obtained three phase switching with each of its phase used two legs. Switching regulation could be divided into two parts which were mosfet switching upper part (p) and lower part (n) at each of A1, A2, B1, B2, C1, and C2 legs. If the upper part of switch was connected then leg was in "on" position (condition 1), while if the lower part of switching was closed then the leg was "off" (condition 0). For example at A1 leg, if the upper switch was connected and lower switch was opened, it meant that A1 leg was "on" (condition 1) and vice versa. Further, this implied that for 6 legs would have 6 switching condition and earned 72 switching vectors with each cycle explained as table 2 .

Table 2

Switching vectors for each transistor

\begin{tabular}{|c|c|c|c|c|c|c|}
\hline & Cond.1 & Cond.2 & Cond.3 & Cond.4 & Cond.5 & Cond.6 \\
\hline A1p & 1 & 1 & 1 & 0 & 0 & 0 \\
\hline A1n & 0 & 0 & 0 & 1 & 1 & 1 \\
\hline A2p & 0 & 0 & 0 & 1 & 1 & 1 \\
\hline A2n & 1 & 1 & 1 & 0 & 0 & 0 \\
\hline B1p & 0 & 0 & 1 & 1 & 1 & 0 \\
\hline B1n & 1 & 1 & 0 & 0 & 0 & 1 \\
\hline B2p & 1 & 1 & 0 & 0 & 0 & 1 \\
\hline B2n & 0 & 0 & 1 & 1 & 1 & 0 \\
\hline C1p & 1 & 0 & 0 & 0 & 1 & 1 \\
\hline C1n & 0 & 1 & 1 & 1 & 0 & 0 \\
\hline C2p & 0 & 1 & 1 & 1 & 0 & 0 \\
\hline C2n & 1 & 0 & 0 & 0 & 1 & 1 \\
\hline
\end{tabular}

As the 2 nd and 3 rd phase signal with $120^{\circ}$ and $240^{\circ}$, the system will use two phase shifter circuits in series(op4 and op5). The circuit consist of inverting opamp with RC network at the reference side. The output will be lagging depends on $\mathrm{RC}$ value. The calculation can be seen in equation 3 . The next step is to create the invert sine wave signal using inverting op-amp. The reference sets to 0 and the feedback voltage divider sets to 1 refer to figure 4 . The calculation of the inverting signal can be seen in equation 4 . From here the signal generator already have 6 sine wave signal at $0^{\circ}, 60^{\circ}$, $120^{\circ}, 180^{\circ}, 240^{\circ}$, and $300^{\circ}$. The final step is to compare these signals with a controlled reference using six opamp comparators for each sine wave. The goal is to obtain controllable switching time (duty cycle) for each leg of the inverter. The prototype device and component can be seen on figure 3 and table 3 . 


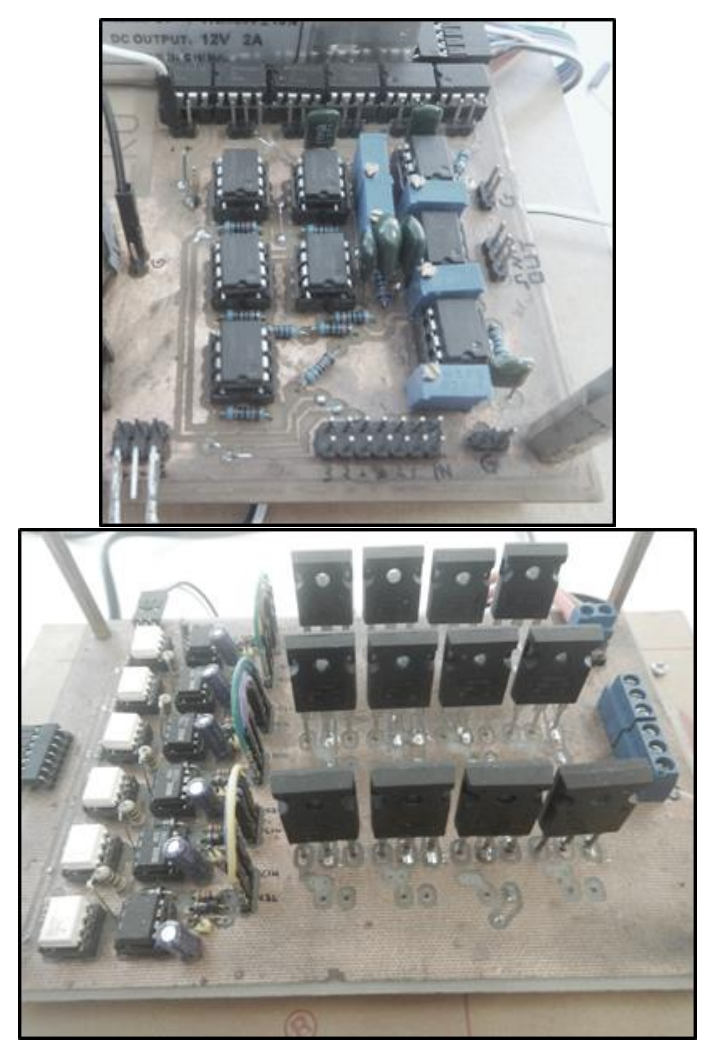

Figure 3.

Three phase six legs signal generator and switching

Table 3

Three phase signal generator components

\begin{tabular}{|l|l|l|}
\hline \multicolumn{3}{|c|}{ resistance $(\Omega)$ and capacitor(F) value } \\
\hline \hline $\mathrm{R} 1=27,57 \mathrm{k}$ & $\mathrm{R} 9=99,1 \mathrm{k}$ & $\mathrm{R} 17=9,8 \mathrm{k}$ \\
\hline $\mathrm{R} 2=102 \mathrm{k}$ & $\mathrm{R} 10=9,72 \mathrm{k}$ & $\mathrm{C} 1=33 \mathrm{nF}$ \\
\hline $\mathrm{R} 3=21,69 \mathrm{k}$ & $\mathrm{R} 11=9,72 \mathrm{k}$ & $\mathrm{C} 2=10 \mathrm{nF}$ \\
\hline $\mathrm{R} 4=0,994 \mathrm{k}$ & $\mathrm{R} 12=2 \mathrm{k}$ & $\mathrm{C} 3=10 \mathrm{nF}$ \\
\hline $\mathrm{R} 5=102,7 \mathrm{k}$ & $\mathrm{R} 13=9,94 \mathrm{k}$ & $\mathrm{C} 4=10 \mathrm{nF}$ \\
\hline $\mathrm{R} 6=9,88 \mathrm{k}$ & $\mathrm{R} 14=9,76 \mathrm{k}$ & $\mathrm{C} 5=10 \mathrm{nF}$ \\
\hline $\mathrm{R} 7=2,625 \mathrm{k}$ & $\mathrm{R} 15=2,08 \mathrm{k}$ & op-amp LF356N \\
\hline $\mathrm{R} 8=112 \mathrm{k}$ & $\mathrm{R} 16=9,8 \mathrm{k}$ & \\
\hline
\end{tabular}

All of the signal data result were observed under Yokogawa DL850.

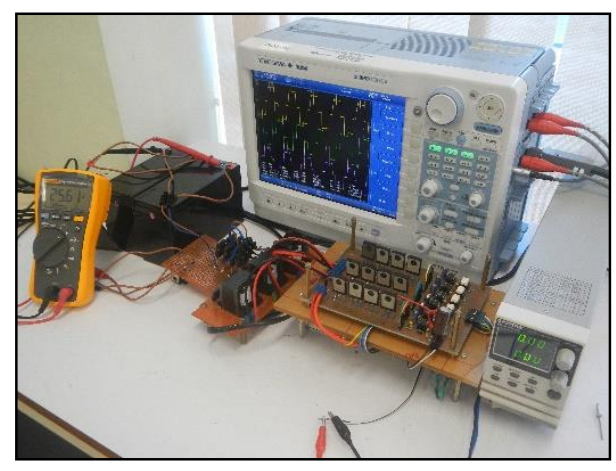

Figure 4.

setup experiment of battery charging from solar PV using DC/DC converter three phase six legs

The final result shows that at the battery side, switching duty cycle makes the inverter inject 26.7 volt and $225 \mathrm{~mA}$ to the battery bank. This chart also show that $49 \%$ duty cycle was not the only maximum current that the inverter can produce. In fact, the inverter can makes the solar PV draw more current nearly at around 26\%$42 \%$ duty cycle, with average current flow at $230 \mathrm{~mA}$.

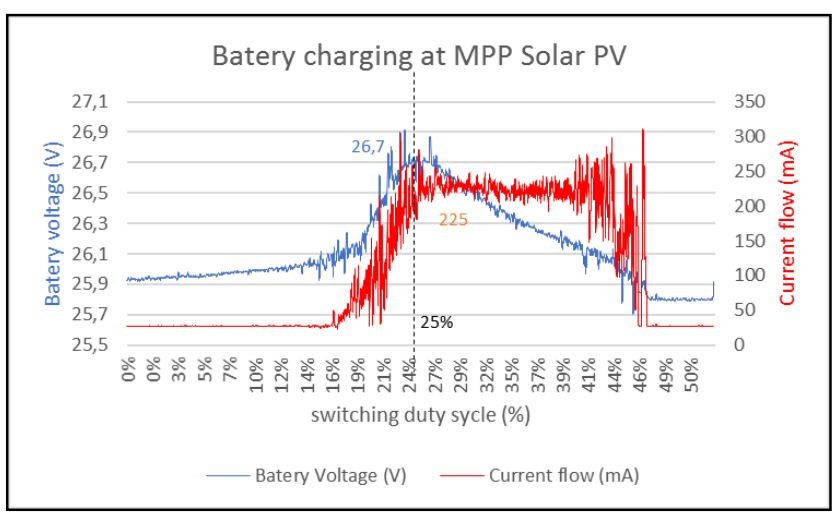

Figure 5

Battery voltage and current performance at optimum duty cycle $25 \%$

\section{CONCLUSION}

This paper has presented that 3phase 6legs DC/DC converter was able to control solar PV impedance to get its maximum power point by adjust the amplitude of the reference manually. The maximum power point of 20watt solar PV was not the only highest value to draw more current to charge the battery bank. To get more precision signal of the signal generator, need to be consider the component must be at the precise value too.

\section{REFERENCES}

[1] Muhammad Prihadi Eko, Three-Phase Six-Legs Full Bridge DC/DC Converter With P\&O MPPT Controller for Battery Charging from Solar PV, International Journal of Environmental Research \& Clean Energy, Vol.7 No.1, 2017.

[2] Fabregat-Santiago, Francisco, et al., Influence of Electrolyte in Transport and Recombination in Dye-Sensitized Solar Cells Studied by Impedance Spectroscopy, Solar Energy Materials and Solar Cells, vol.87 no.1 pp. 117-131, 2005.

[3] Tse, K. K., Ho, M.T., Henry S, Chung H., Hui, S.Y., A Novel Maximum Power Point Tracker for PV Panels Using Switching Frequency Modulation, Power Electronics, IEEE Transactions vol.17 no.6, pp. 980-989, 2002.

[4] Bhatnagar, Pallavee, and R. K. Nema, Maximum Power Point Tracking Control Techniques: Stateof-The-Art in Photovoltaic Applications, Renewable and Sustainable Energy Reviews, vol.23, pp. 224-241, 2013.

[5] EftichiosKoutroulis, Kostas Kalaitzakis, Development of A Microcontroller-Based, Photovoltaic Maximum Power Point Tracking Control System, IEEE Transactions on Power Electronics, vol.16 no.1, 2001. 
[6] Zhang, Fan, Fang Z. Peng, and Zhaoming Qian, Study of The Multilevel Converters in DC/DC Applications, Power Electronics Specialists Conference, PESC 04. 2004 IEEE 35th Annual. vol.2, 2004.

[7] Kim, Eun-Soo, Kee-Yeon Joe, Moon-Ho Kye, Yoon-Ho Kim, and Byung-Do Yoon, An Improved Soft-Switching PWM FB DC/DC Converter for
Reducing Conduction Losses, Power Electronics, IEEE Transactions vol.14 no.2, pp. 258-264, 1999.

[8] Lee, Il-Oun, and Gun-Woo Moon, Soft-Switching DC/DC Converter With a Full ZVS Range and Reduced Output Filter for High-Voltage Applications, Power Electronics, IEEE Transactions vol.28 no.1, pp. 112-122, 2013. 